\title{
Heaven, hell, and saving souls: Were we always wrong?
}

\author{
Pieter Verster \\ Research fellow \\ Department of Practical and Missional Theology \\ Faculty of Theology \\ University of the Free State, South Africa \\ E-mail:versterp@ufs.ac.za \\ Doi: https://doi.org/10.46222/pharosjot.102.023
}

\begin{abstract}
Is the Bible clear on heaven, hell, and eternity? This question is important for the mission of the church. In recent books, N.T. Wright challenges the concepts of heaven and hell and the saving of souls for eternal heaven or the proclamation of judgement to those who are lost. Although his view is one of critical realism, which differs substantially from Bultmann's demythologizing of the Bible as viewpoint, there are some similarities. Hans Küng also has some questions regarding traditional views on eternity. Bram van de Beek, however, explains that it is necessary to mention that this world is not our abode. In discussing biblical texts such as many parables and many of Paul's utterances, one must regard the references to eternal life and the reality of heaven and hell as essential in the proclamation of the gospel. God's grace is, however, much more glorious and encompassing than his wrath.
\end{abstract}

Keywords: Heaven, hell, eternity, salvation, gospel.

\section{Introduction}

Currently, the way in which to conduct mission and evangelism is again under discussion. There is even the question as to whether it is at all necessary. It may still be relevant in another form, but the question is whether it is at all necessary to proclaim that salvation in Christ leads to glory in heaven and rejection of Christ leads to suffering in hell. Different perspectives challenge the literal view of heaven and hell; the proclamation that people should be converted to Christ, in order to receive eternal life in heaven, and the resurrection of the body in Christ. Even theologians such as N.T. Wright hold a view that evaluates eschatology differently from the traditional theological views. To engage theologians in this matter entails aspects of eschatology and the way in which people are saved. To accomplish this, interaction with the theologians as well as exegetical and hermeneutical evaluation of biblical texts are essential.

\section{Implications of new views}

\section{N.T. Wright's view}

N.T. Wright recently wrote books on the issues of salvation and of heaven and hell. His suggestions can be summarized under the following main points.

1. The concepts of heaven and hell have more to do with Plato's views than with the views explained in the New Testament. 
Wright (2008:19) writes concerning the book of Revelation: 'Heaven, in the Bible, is not a future destiny but the other, hidden, dimensions of our ordinary life - God's dimension, if you like. God made heaven and earth: at the last He will make both and join them together forever.'

Concerning hell, Wright (2008:176) writes:

The point is that when Jesus was warning his hearers about Gehenna, he was not, as a general rule, telling them that unless they repent in this life they would burn in the next one. As with God's kingdom, so with the opposite, it is on earth that things matter, not somewhere else (italics, Wright).

Wright (2008:150) is of the opinion that the idea of hell can be suggested from the parables only by extension and extrapolation. He explains that the reference to paradise in Luke, when the murderer on the cross asks Jesus to think of him and Jesus answers that today you will be with me in paradise, is not about a final destination.

2. Salvation does not mean that we go to heaven.

According to Wright, salvation has to do with this world and the final resurrection of the body in the continuation of this world into the new world. Salvation is not something regarding the rejection of this world and a new life in heaven, but a new disposition towards this life, accepting one's vocation here and now. As this world will continue into the next, new life starts in this world and will be completed in the resurrection of the body in the next.

Witherington III (1997:1078) explains that Wright opines that Jesus cannot be included in categories of modern Judaism, or modern Western Christianity, or modern Western secularity. Instead, 'Jesus continues to raise profound questions about what it means to be human, what it means to be a Jew, what it means to be a Christian'.

3. Eternal life is the resurrection of the body.

Eternal life already starts now, but it will be consumed in the glory of the resurrected body. Eternal life is not living in 'heaven' for ever. The resurrection of Christ has to do with this resurrection of the body (Wright 2008:38). Wright (2008:66) accepts the death of Christ and his resurrection. It brings salvation in the sense that this life is made new and that creation is fulfilled in the new creation.

4. Sin, death, and evil are when God judges in this world.

Evil is not created; it is idolatry, where God is not honoured and worshipped as he should be. Death obtained a new dimension while part of God's creation and becomes spiritual death (Wright 2008:95). Byassee (2014:40) shows that Wright regards hell as an idea of the Middle Ages and not of the Jews and Jesus.

5. The new creation is the way in which God renews his good creation. Wright (2008: 90) polemicizes against the idea of simply passing through and opines that this view is Platonic. 
Wright (2008:91) writes:

the central Christian affirmation is that what the creator God has done in Jesus Christ, and supremely in his resurrection, is what he intends to do for the whole world - meaning by world, the entire cosmos with all its history (italics, Wright).

The renewal of creation means this life is also all important.

Dunson (2016:217) regards Wright's view as that salvation has to do with the whole cosmos and not individual salvation.

6. Judgement.

Wright (2008:141) explains the final judgement:

The main point to notice, once more, is that the future judgement is highlighted basically as good news, not bad. Why so? It is good news, first, because the one through whom God's justice will finally sweep the world is not [a] hard-hearted, arrogant, or vengeful tyrant but rather the Man of Sorrows, who is acquainted with grief: the Jesus who loved sinners and died for them; the Messiah who took the world's judgement upon himself on the cross.

In his book, God and the pandemic: A Christian reflection on the coronavirus and its aftermath, Wright (2020:23) is of the opinion that, when we talk about God's kingdom and God's ultimate future, it is not about going to heaven and leaving this world behind.

Willitts (2015:352) explains that, according to Wright, Jesus changed the views and expectations of the Jewish world view concerning Torah, land, and Temple.

7. Evangelism does not concern the saving of souls, but the accepting of responsibility for this life, the present creation that continues into new creation.

Wright (2008:227) does not reject the fact that many became Christian because of the proclamation of heaven and hell, but he has a new perspective:

The power of the gospel lies not in the offer of a new spirituality or religious experience, not in the threat of hellfire (certainly not in the threat of being 'left behind'), which can be removed if only the hearer checks this box, says this prayer, raises a hand, or whatever, but in the powerful announcement that God is God, that Jesus is Lord, that the powers of evil have been defeated, that God's new world has begun. This announcement, stated as a fact about the way the world is rather than as an appeal about the way you might like your life, your emotions, or your bank balance to be, is the foundation of everything else. Of course, once the gospel announcement is made, in whatever way, it means instantly that all people everywhere are gladly invited to come in to join the party, to discover forgiveness for the past, an astonishing destiny in God's future, and a vocation in the present. And in that welcome and invitation, all the emotions can be, and one hopes will eventually be, fully engaged. 


\section{Hans Küng on eternal life}

Küng also wrote an important book on eternal life. He is of the opinion that the belief about heaven in Christian faith should be about an ultimate and initial reality. He explains this in three propositions. First, Küng (1980:177) explains that heaven is not a 'world above', but that God is in this world and that heaven is in this world. Secondly, Küng (1980:177) rejects the idea that heaven is something 'beyond' where God is outside this world. Lastly, Küng (1980:178) rejects the notion that heaven is a place, but he understands it as a mode of being, since God cannot be limited to space: 'The heaven of faith is nothing other than the hidden, invisible-incomprehensible sphere of God which, far from being out of reach of earth, completes everything in good and provides a share in God's rule and kingdom.'

Concerning hell, Küng (1980:175) explains that he does not understand hell to be a mythological place, but the final exclusion of God from the person's life. He is of the opinion that the New Testament does not explain a reality after death, but the reality of the seriousness of God's claim on the person's life in this world. Rejecting God's claim means that the person judges him-/herself in this world but must also turn to God's universal mercy. Therefore, the concept of eternal punishment must be subjected to God and the possibility of all-embracing mercy. Küng (1980:175) writes: 'The fact that condemnation to hell is not the last word in the light of the crucified and risen Christ has decisive consequences particularly here and now.'

\section{Bram van de Beek: A challenging position}

Van de Beek (2008:13ff.) is very critical towards modernistic theologians challenging the concept of life after death. He refers to the fact that Käsemann rejected Bultmann's view that the whole world view of the Bible should be revisited, especially concerning life after death regarding the death and resurrection of Christ. Van de Beek (2008:83ff.) explains that eschatology has everything to do with the living Christ. His resurrection is not a spiritual, but a physical reality. Although the resurrection of the dead will also be eschatological, it does remain a reality in time and space. It is unthinkable to have life after death without relations. Life after death is not only a spiritual remembrance. Therefore, Van de Beek is of the opinion that heaven and hell are a reality, although the way in which we must understand it differs in the Bible.

The early church fathers also had different views on life after death, but many had a clear vision of heavenly bliss in the resurrection after death in Christ, and torment if not in Christ. According to him, texts such as 2 Corinthians 5:1; Acts 7:56; John 14:2; Philippians 1:23, and Thessalonians $4: 17$ attest to the glorious life after death in Christ. He explains that the Bible points to torment for those who die in their sin. Roman Catholic theology has the concept of 'purgatory', a challenging burning fire to cleanse you after death.

The Reformers rejected the idea, because they believed that Christ's death on the cross is sufficient for salvation of all sin. Images of Gehenna and fire in the Bible certainly warn of judgement. Proclaiming Christ means that new life is possible in $\mathrm{Him}$, and that salvation must always be proclaimed before judgement. This world is not our abode; total regeneration will take place in the consummation of the cosmos (Van de Beek 2008). The new creation is not a continuation of this world. It is totally new in Christ. Salvation is being in Christ and living and dying in Him. 


\section{Bultmann's radical challenge to world view}

Bultmann's position in this regard is important. He opines that the world view of the New Testament differs totally from the contemporary one. Therefore, much of the New Testament is mythical.

Morgan (2020:305) explains that new questions about the historical-critical schools led to Bultmann's views being challenged: 'Biblical scholarship has advanced by rejecting hypotheses which have proved implausible in the light of new evidence or assessments.' Bultmann's view of mythology is important.

Malan (2015:2) regards Bultmann's view of mythology to be understood as an explanation of human existence. Demythologization views the essence of human existence.

Jennings (2018:35) explains that Bultmann has an existential interpretation: 'Bultmann's existentialist interpretation of the Gospel kerygma centers on trusting God rather than the false stumbling block of biblical literalism.' Trust in God is radical in Bultmann's demythologizing method. He wants to proclaim the gospel but in a totally new world. The mythological world of the Bible has changed drastically (see Bultmann 1961:1-2). To proclaim the gospel is the essence of Jesus' message, without the mythological aspects (Jennings 2018:36).

Baasland (2015:455) shows that Bultmann was very sceptical about the historical Jesus having an impact on our understanding of the Christian faith.

Barclay (2015:203) is of the opinion that Bultmann did not want to first 'describe, as accurately as possible, the historical content and meaning of the text, and then one thinks about (or asks a theologian to think about) what this might mean in theological terms.' To him, this is impossible.

Van Wyk (2017:6) opines that Bultmann wants to keep to the essence of theological issues. It must be done historical-critically.

Baasland (2015:440) explains that Bultmann wants to apply his dialogical approach to Jesus' teaching, not to his life and personality. Baasland (2015:440) is critical concerning this: 'These distinctions are indeed a bit arbitrary. Is it possible to make this distinction between teaching and life? Life/work and teaching should be one, and why should teaching be approached dialogically and life/work be treated with "objective viewpoints"?'

Van Wyk (2015:8) also has issues about this. It is, however, not clear that Bultmann wants the freedom of the believer to include service to the neighbour. Wars and so on led to his loss of belief in the goodness of human beings and believers.

Regarding the apocalyptic aspect of Barth's and Bultmann's views, Congdon (2018:54) explains that they 'reject the quantitative difference of apocalyptic in favour of the qualitative difference of eschatology, which they understand as referring not to the chronological imminence of God's future kingdom but to the transcendent otherness of God's inbreaking action in Christ.' Congdon mentions that, for Bultmann, eschatology is realized eschatology. The decisive eschatological has already occurred, according to him, in Christ. It has to do with the present situation.

Käsemann has another view. According to him, apocalyptic is the mother of all Christian theology and is all about Jesus' second coming in glory. 'Käsemann thus identifies apocalyptic here with 
future eschatology. This becomes important when he treats the theology of Paul, which he sees as "a balance between present and future eschatology" (Congdon 2018:45)'.

Zahl (1996:416) summarizes these views as follows:

Käsemann sees Bultmann's crucial mistake contained in the following idea: Modern man is able, when and insofar as he has been formed by the preaching of the Christian message, to receive instruction from Jesus' preaching concerning the constitutive structures of his existence, and to hear the call to live according to these structures.

But not from the life of the historical Jesus.

This means that an essential truth is conveyed, but that it should be reinterpreted in light of the new situation and world view in which we find ourselves. Heaven and hell, specifically, are not part of our new understanding of the world in which we are living. Although the world view has changed, the new understanding does not take into account that the Word is still the same, that there is no other way of explaining the reality of heaven and hell in the way in which the New Testament does, and that it is not possible to reject the notion because of different views in world view. The reality of heaven and hell can indeed still be explained in the present reality.

To summarise: Bultmann (1958:s.p.) puts it as follows:

First, it must again be stressed that the eschatological message of Jesus, the preaching of the coming of the Kingdom and of the call to repentance, can be understood only when one considers the conception of man which in the last analysis underlies it, and when one remembers that it can have meaning only for him who is ready to question the habitual human selfinterpretation and to measure it by this opposed interpretation of human existence. Then it becomes obvious that the attention is not to be turned to the contemporary mythology in terms of which the real meaning in Jesus' teaching finds its outward expression. This mythology ends by abandoning the fundamental insight which gave it birth, the conception of man as forced to decision through a future act of God. To this mythology belongs the expectation of the end of the world as occurring in time, the expectation which in the contemporary situation of Jesus is the natural expression of his conviction that even in the present man stands in the crisis of decision, that the present is for him the last hour. To this mythology belongs also the figure of Satan who now fights against the hosts of the Lord. If it is true that to Jesus the world can be called bad only in so far as men are bad, that is, are of evil will, then it is clear how little the figure of Satan really meant to him.

\section{Interaction with the theologians}

Wright is not a Bultmannian; he rather links himself to the concept of critical realism (see Porter \& Pitts 2015:278 regarding critical realism). He does not demythologize the Bible, but he is also of the opinion that many aspects of the references to heaven and hell are not consistent with the new realistic aspects of the Bible overall.

Not only Bultmann challenges the direct implications of biblical texts. Since the rise of historicalcritical exegesis, with notions such as redaction criticism, form criticism, and language criticism, the direct relation of text has been challenged. Narrative theology also understands the text from the perspective of its implications for the narrative and not the direct implications. Canon criticism 
even regards some texts and pericopes as not acceptable for inclusion in the canon. Even some aspects of Paul's letter are rejected as not compatible with Jesus' message of love. However, one must take the biblical text extremely seriously. First, although we have differences in world view, we share the same environment and can relate to the notion such as Gehenna. The essence remains the same. Changes in metaphors and images do not mean that a total new understanding is possible, as Bultmann suggests. There is a line of communication that remains the same. Metaphors and images always relate to all people. The speech act theory helps us understand a text better. One can expand the speech act theory to a text communication theory, by making the implications of a text clear without changing its intent. In this theory, the minimum is required in communication. All that is extra leads to implications (Van Coller 2019:181). This theory helps understand some aspects of eternal life as explained in the Bible.

\section{Hermeneutical and exegetical evaluation}

The issue regarding the parables is important. If the parables (Matthew 13:18-30; Mark 4:13-20; Luke 8:11-15; Matthew 18:10-14; Luke 15:3-7, 12:13-21 and 16:19-31) do give some information of life after death, heaven and hell are real. Some suffer extremely in a burning fire in Gehenna/hell. Some are at the bosom of Abraham in heaven. Like the good grain and the weed, there is separation in death. Jesus warns that there is grinding of teeth in hell. Fear God, He warns, the One who can judge and send people to death in hell. Wright views the parables not as a reality of heaven and hell, but as a warning for this life. Van de Beek, on the other hand, opines that they provide aspects of life after death. Parables about heaven and hell should be revisited. Should they be disregarded because of differences in world view, as suggested by Bultmann, or by the fact that they are not numerous, as suggested by Wright (2008) and Bell (2011)? The speech act theory helps in this regard. The minimum would simply be an explanation of life after death. The parables explain the reality of heaven and hell in much more elaborate terms.

It must be clear that the parables do give information on life after death and the reality of heaven and hell. Jesus' warning is not only for this life. It has implications for eternal life. The warning is a warning in love to help people turn from their evil ways.

Luke 16:19-31 must be scrutinized. In this parable, life after death is related to aspects of the world view of the time. Heaven is viewed as above and hell as across a divide. It is a realistic view of separation after death. Some receive glory, others suffer torment to such an extent that they want to return to life to warn their brothers. The elaborations in the parable transgress the minimum in light of the speech act idea. This means that special attention should be paid to it. The brother accepts that, if he does not warn others, they could suffer the same fate. The essence of the parable is that, after death, there is separation between those in glory and those who are rejected. In this regard, the parable tells about life after death in Jesus' time. The reader would most probably view it in this way (see also Matthew 25:31-46). During the Middle Ages and the Reformation, the same. Bultmann, Wright (2008), Bell (2011) and modern human beings reject this view. It must be clear that one cannot establish a full eschatology from these verses. Once can, however, infer that there is the reality of separation in glory and torment after death. Liefeld (1984:s.p.) explains this as follows:

Thus understood, the story makes a powerful case for (1) the future reversal of the human condition (cf. 6:20-26), (2) the reality of future judgment based on one's decisions in this life, and (3) the futility of even a resurrection to persuade those who persist in rejecting God's revealed word. 
Nolland (1993) is of the opinion that the fate suffered by the rich man is consistent with judgement. The warning of the parable is not only about this life, but also about life after death.

How does one receive eternal life with God? In this instance, Romans 5 is important. First, because Christ gave his life for sinners. He surrendered himself for our salvation. The speech act theory enables one to understand that the following aspects transgress economy. Paul explains much more than is needed in the minimum. The death of Christ for sinners is explained in elaborate terms to highlight the full implications thereof. Harrison (1976:s.p.) highlights the glorious salvation in Christ, and Dunn (1988:s.p.) explains that the One (Christ) is sufficient to change the reality of sin:

Here, we might note, is another indication of the theology of sacrifice, at least according to Paul: the death of the sacrifice reconciles God to the sinner, presumably by removing (through its destruction) the cause of hostility (the powerful hold of $\sin$ ) by means of the sinner's identification with the sacrifice in its death.

It is very important that God's grace is, according to Romans 5, much more abundant than His wrath. Because grace is so abundant, eternal life in Christ is guaranteed (Dunn 1988:s.p.). People of faith in God in Jesus Christ receive this gift. Hell remains a serious reality, but God, in his abundant grace, wants to save many more people through Jesus on the cross. His grace is abundant and He wishes all to come to him (1 Timothy 2:3-4).

It is also important to seek, first, the kingdom of God and to have our treasures in heaven (Matthew 6:19-21; Luke 12:33-34). In expectation of the second coming of Christ and the judgement, the believers long for eternal life with God. Colossians 3:1-3 explains that we should look up to heaven.

The great commission also explains in depth that there is more to this than this life. Many issues are explained more fully than the minimum.

Jesus' words on the cross to the murderer, in Luke 23:39-43, read together with Paul's words in Philippians 3:7-14 and 1:23, are clear. It can hardly be attributed to a world view and not to a wonderful reality. Hebrews explains that the Christians gladly ceded their possessions in this world, because they knew that they have an abode in heaven.

Paul speaks about final judgement in Acts. His speech, as Luke reports, clearly states that there will be final judgement. Read together with Mark, Luke, and Matthew, one must accept the separation of goats and sheep in the final judgement. This judgement is clearly not only about life on earth.

Nowhere is salvation and future eternal life clearer than in John. Note Jesus' reference to life in Him which naturally already starts now on earth and continues in life after death and in the final resurrection to glory or to destruction. The way to eternal life is through the Good Shepherd. Jesus' message in John 14 that there are many rooms in His Father's house is very clear.

Revelations, written for those who are persecuted, is clear about the fact that this world is not the believer's final abode. Although Revelations is written in the apocalyptical genre, it is again impossible to perceive the implications for eternity.

Paul makes it very clear in 2 Corinthians 5:1-10 that he longs for life with God in the heavenly abode. The present life, as in a tent, must be broken down, in order to obtain the abode in heaven. 
Paul mentions the wonders of eternal life in 1 Corinthians 15, where he deals with the resurrection of the body.

These views do not lead to dualism, namely that this world is not important, but that only the church and eternal life are important. The perspective on eternal life does not restrict the importance of this life. It opens the view to more than this world. Mission must, therefore, warn of sin and proclaim salvation. Mission also has implications for this life. Goheen (2019:14) writes:

Mission in our vocations is not simply a matter of evangelism and personal ethics - although it is that in Wright's work - but also to embody God's new creation in those areas in such a way as to raise questions, to set up signposts that say there is a different way to be human.

Mission is still the acts of the Triune God, Father, Son and Holy Spirit who, in Jesus Christ, brings glory and salvation for people in the world. It proclaims that Jesus is true Lord and that He should be acknowledged as Lord and that He, through the Holy Spirit, leads people out of darkness into God's glorious light, so that they can enjoy the fullness of life in this world, and receive eternal life in Jesus Christ. Mission is to live according to this confession, so that the church, through the Holy Spirit, in love provides help and blessings in expectation of eternity (Verster 2020:22)

\section{Conclusion}

Modern human beings reject the reality of heaven and hell. Interaction with theologians shows their different views. Although one must take note of all these views, it remains essential to take full note of the Biblical explanation of life on earth and eternity. The fullness of the grace of God in Christ is much more abundant than His wrath, but it remains essential to proclaim to all to come to Christ, in order to receive this blessing and be saved from death. Mission must always proclaim, be reconciled with God in Christ.

\section{References}

Baasland, E. (2015). 'Consistent Jesus research?: Bultmann's Die Geschichte der synoptischen Tradition (1921) and Jesus (1926) Revisited', Ephemerides Theologicae Lovanienses, 91(3):415460. $<\mathrm{https}$ ://search-ebscohostcom.ufs.idm.oclc.org/login.aspx?direct=true\&db=rfh\&AN=ATLAiBCA160705001526\&site=ehostlive\&scope=site $>$ (Retrieved July 5, 2021).

Barclay, J.M.G. (2015). 'Interpretation, not repetition: Reflections on Bultmann as a theological reader of Paul', Journal of Theological Interpretation, 9(2):201-209. <https://search-ebscohostcom.ufs.idm.oclc.org/login.aspx?direct=true \&db=rfh\&AN=ATLAn3840659\&site=ehostlive\&scope=site $>$ (Retrieved July 5, 2021).

Bell, R. (2011). Love wins: At the heart of life's big questions. Londen: Collins.

Bultmann, R. (1958). Jesus and the word. <https://www.religion-online.org/book-chapter/chapter2-the-teaching-of-jesus-the-coming-of-the-kingdom-of-god/>(Retrieved July 5, 2021).

Bultmann, R. (1961). Kerygma and myth: A theological debate. <http://www.religion.emory.edu/faculty/robbins/Pdfs/BultmannNTMyth.pdf> (Retrieved July 6, 2021). 
Byassee, J. (2014). 'Surprised by Wright: The Bible scholar's goal is to massively revise the way we talk about the Christian faith: By many accounts, he's already succeeded', Christianity Today, 58(3):36-43. $<$ https://search-ebscohostcom.ufs.idm.oclc.org/login.aspx?direct=true \&db=rfh\&AN=ATLA0001979474\&site=ehostlive\&scope=site $>$ (Retrieved July 5, 2021).

Congdon, D.W. (2018). 'Apocalypse as perpetual advent: The apocalyptic sermons of Rudolf Bultmann', Theology Today, 75(1):51-63. <https://search-ebscohostcom.ufs.idm.oclc.org/login.aspx?direct=true\&db=rfh\&AN=ATLAiAZI180507000198\&site=ehostlive\&scope $=$ site $>$ (Retrieved July 5, 2021).

Dunn, J.D.G. (1988). Romans 1-8. Waco, TX: Word Books. (Word Biblical Commentary, Vol. 38A).

Dunson, B.C. (2016). 'N.T. Wright's Paul and the faithfulness of God', Puritan Reformed Journal, 8(2):212-240. $<$ https://search-ebscohostcom.ufs.idm.oclc.org/login.aspx?direct=true \&db=rfh\&AN=ATLAn4477381\&site=ehostlive\&scope $=$ site $>$ (Retrieved July 5, 2021).

Goheen, M.W. (2019). 'A conversation with N.T. Wright about a missional hermeneutic and public truth', Presbyterion, 45(2):8-16. <https://search-ebscohostcom.ufs.idm.oclc.org/login.aspx?direct=true \&db=rfh\&AN=ATLAn4647548\&site=ehostlive\&scope=site $>$ (Retrieved July 5, 2021).

Harrison, E.F. (1976). Romans. In F.E. Gæbelein (Ed.). The Expositor's Bible commentary: Romans through Galatians: With the New International Version of the Holy Bible. Zondervan, Grand Rapids, MI (The Expositor's Bible Commentary Vol. 10).

Jennings, B.S. (2018). 'Rudolf Bultmann as theologian of radical trust in the Gospel', Currents in Theology and Mission, 45(4):35-40. <https://search-ebscohostcom.ufs.idm.oclc.org/login.aspx?direct=true \&db=rfh\&AN=ATLAiG0V181112001618\&site=ehostlive\&scope=site $>$ (Retrieved July 5, 2021).

Küng, H. (1980). Eternal life? (Trans. by E. Quinn). London: Collins.

Liefeld, W.L. (1984). Luke. In F.E. Gæbelein (Ed.). The expositor's Bible commentary: Matthew Luke: With the New International Version of the Holy Bible. Zondervan, Grand Rapids, MI.

Malan, G. (2015). 'Die Nuwe Testament en mitologie: Die probleem van die ontmitologisering van die Nuwe-Testamentiese verkondiging: Bultmann se 1941-opstel weer bekyk', Hervormde Teologiese Studies, 71(3):1-8. <https://search-ebscohostcom.ufs.idm.oclc.org/login.aspx?direct=true \&db=rfh\&AN=ATLAn3828275\&site=ehostlive\&scope=site $>$ (Retrieved July 5, 2021).

Morgan, R. (2020). 'Bultmann in retrospect', Journal for the Study of the New Testament, 42(3):303-324. $<$ https://search-ebscohostcom.ufs.idm.oclc.org/login.aspx?direct=true \&db=rfh\&AN=ATLAiGW7200316001478\&site=ehost -live\&scope=site $>$ (Retrieved July 5, 2021).

Nolland, J. (1993). Luke 9:21-18:34. Dallas, TX: Word Books. (Word Biblical Commentary, Vol. 33B). 
Porter, S.E. \& Pitts, A.W. (2015). 'Critical realism in context: N.T. Wright's historical method and analytic epistemology', Journal for the Study of the Historical Jesus, 13(2-3):276-306. $<$ https://search-ebscohost-

com.ufs.idm.oclc.org/login.aspx?direct=true \&db=rfh\&AN=ATLAn3894906\&site=ehostlive\&scope=site $>$ (Retrieved July 5, 2021).

Van Coller, H.P. (2019). N.P. van Wyk Louw as satirikus. Acta Theologica Supplementum 28(10) Festschrift Pieter Verster:163-195. DOI: http://dx.doi. org/10.18820/23099089

Van de Beek, A. (2008). God doet recht: Eschatologie als christologie. Zoetermeer: Meinema. (Spreken over God 2.1).

Van Wyk, G. (2017). 'Die lewe en werk van Rudolf Bultmann (1884-1976): 'n Leksikografiese bydrae tot Reformasie 500', Hervormde Teologiese Studies, 73(1):1-6. <https://searchebscohost-

com.ufs.idm.oclc.org/login.aspx?direct=true \&db=rfh\&AN=ATLAn4260879\&site=ehostlive\&scope=site $>$ (Retrieved July 5, 2021).

Van Wyk, I.W.C. (2015)> 'Rudolf Bultmann se verstaan van vryheid', Hervormde Teologiese Studies, $\quad 71(3): 1-8 . \quad<$ https://search-ebscohostcom.ufs.idm.oclc.org/login.aspx?direct=true \&db=rfh\&AN=ATLAn3828246\&site=ehost-

live\&scope=site $>$ (Retrieved July 5, 2021).

Verster, P. (2020). Die wonderbare Heilige Gees én die Vader van liefde: 'n Missionêre teologie. Bloemfontein: Sunbonani.

Willitts, J. (2015) 'Jesus, the Kingdom and the Promised Land: Engaging N.T. Wright on the question of kingdom and land', Journal for the Study of the Historical Jesus, 13(2-3):347-372. $<$ https://search-ebscohost-

com.ufs.idm.oclc.org/login.aspx?direct=true \&db=rfh\&AN=ATLAn3896487\&site=ehost-

live\&scope=site $>$ (Retrieved July 5, 2021).

Witherington, B., III (1997). 'The Wright quest for the historical Jesus', The Christian Century, 114(33):1075-1078. <https://search-ebscohostcom.ufs.idm.oclc.org/login.aspx?direct=true\&db=rfh\&AN=ATLA0001005872\&site=ehost-

live\&scope=site $>$ (Retrieved July 5, 2021).

Wright, N.T. (2008). Surprised by hope: Rethinking heaven, the resurrection and the mission of the church. New York: HarperOne.

Wright, N.T. (2020). God and the pandemic: A Christian reflection on the coronavirus and its aftermath. Grand Rapids, Mi.: Zondervan Reflective.

Zahl, P.F.M. (1996). 'A new source for understanding German theology: Käsemann, Bultmann, and the "New Perspective on Paul", Sewanee Theological Review, 39(4):413-422. $<$ https://search-ebscohost-

com.ufs.idm.oclc.org/login.aspx?direct=true\&db=rfh\&AN=ATLA0001010871\&site=ehost-

live\&scope=site $>$ (Retrieved July 5, 2021). 